University of Warwick institutional repository: http://go.warwick.ac.uk/wrap This paper is made available online in accordance with publisher policies. Please scroll down to view the document itself. Please refer to the repository record for this item and our policy information available from the repository home page for further information.

To see the final version of this paper please visit the publisher's website. Access to the published version may require a subscription.

Author(s): Anne Gerritsen

Article Title: Friendship through Fourteenth-Century Fissures: Dai Liang, Wu Sidao and Ding Henian

Year of publication: 2007

Link to published version:

http://dx.doi.org/ 10.1163/138768007X171713

Publisher statement: None 


\section{Friendship through Fourteenth-Century Fissures: Dai Liang, Wu Sidao and Ding Henian ${ }^{1}$}

Anne Gerritsen

(Warwick University)

\section{Introduction}

Relations between men in imperial China, in so far as we can know them today, were to a significant extent shaped by the setting in which they occurred: men passed the civil service examinations together, served in office together, and shared kinship links. ${ }^{2}$ Such relationships on the whole had clearly defined contexts within which they were established and given meaning. Relationships between men beyond these defined contexts we often describe as "friendships," although thus far little work has been done to establish what meanings such "friendships" may have held in theory and practice. ${ }^{3}$ The studies in this issue all seek to further our understanding of the changing meanings assigned to friendships between men in imperial China, and the multiple ways in which such friendships were performed. ${ }^{4}$

Rather than seeking to define the idea of friendship, this essay analyzes one set of male bonds, in an attempt to understand the possible range of meanings assigned to the practice of friendship in the fourteenth century. To do this, I will look at the relationships between three men in the Yuan-Ming transition: a writer and poet from Jinhua金華 prefecture (Zhejiang province) who refused to serve Zhu Yuanzhang 朱元章 (r.13681398), the first emperor of the Ming dynasty, and remained loyal to the Yuan dynasty until his death in 1383; a poet of Central Asian origins, who was thirty-three years old when the Yuan fell and lived until the end of Yongle's 永樂reign (1403-1424); and a 
fourteenth-century man from Ningbo寧波prefecture (Zhejiang province) who served Zhu Yuanzhang as local magistrate. The 'fissures' from my title should be clear: these three men grew up in different regions, had different ethnic backgrounds, and made very different political choices. And yet, from their writings we know that there were ongoing links between these men. ${ }^{5}$ Through the exchange of writings in a variety of genres, these men established intimate bonds. It is the nature of the bonds between these three men across the fissures of the fourteenth-century terrain, and the implications of those ties for our understanding of friendship and gender, that I am interested in exploring.

The fourteenth century context and the traumatic ruptures of the transition from Yuan to Ming are especially relevant for this discussion not only because the fourteenth century has thus far received less scholarly attention than the fifteenth and sixteenth centuries, but also because they provide a significant historical contrast to the environment of the mid to late Ming. During the wars of the Song-Yuan transition, the political instability of the Yuan dynasty, and the war-torn and bandit-rife chaos of the Yuan-Ming transition, elite men had few opportunities to travel widely and establish social networks (you遊), or to engage in the leisurely pursuits of, say, 'musiking' or philosophical debate. ${ }^{6}$ Moreover, under Yuan rule, both entering and passing the civil service examinations were more difficult for Han men than it had been during the Song, and than it would become during the early Ming. Pathways to government service for men without Mongol or semu色目 status, the designation used by the Mongols for a wide range of Western and Central Asian elites in China, were highly limited during this period. ${ }^{7}$ With such restrictions on examinations and government service, and on the 
cultural life of elite men, there were precious few social spaces within which male relationships and friendships among men that hailed from different parts of China could be forged in the years before the Ming government was fully established. ${ }^{8}$

In contrast, in the late Ming environment of commercialization, social and geographic mobility, and with the rise of individuals' moral autonomy, "a cult of friendship" would arise. ${ }^{9}$ During the more politically stable and commercially developed later centuries of the Ming, there were far more opportunities for men to travel and interact than during the Yuan, as the papers by Joseph Lam and Martin Huang amply illustrate. The social and economic developments of the late Ming seem to have created a social and cultural landscape within which the celebration of male friendships could flourish in ways that were far less visible in the late Yuan and early Ming dynasties. Nevertheless, of course male relationships were also established and maintained in that period of disruption and uncertainty, and I think it is relevant to ask how they fit into the story.

\section{Three Men}

The oldest of the three was Dai Liang戴良, born in 1317 in Pujiang浦江 county in Jinhua prefecture, where he studied with such illustrious Jinhua men as Liu Guan柳貫 (12701342), Huang Jin黃洷 (1277-1357) and Wu Lai吴莱 (1297-1340). ${ }^{10}$ After the fall of the

Song to the Mongols, Pujiang county hosted gatherings of Song loyalist poets, and became associated with Song loyalist sentiments. ${ }^{11}$ As Langlois has eloquently explained, however, this Song loyalism was not so much an expression of anti-Mongol sentiment, as 
"an impetus of dedicated service to the prevailing regime, no matter what it happened to be." 12 Scholars from Pujiang, and more generally from Jinhua, were committed to the intellectual ideals and cultural values of the Confucian tradition, and they were willing to go so far as to "reformulate" the role of the scholar in order to safeguard the tradition under the new political circumstances of Yuan rule. ${ }^{13}$ When Zhu Yuanzhang arrived in the 1350s, these same Jinhua scholars took it upon themselves to initiate Zhu in the statecraft teachings of the Confucian tradition. ${ }^{14}$ Loyalism, in other words, for these Pujiang loyalists did not yet have the resonances of a service to one regime only, nor the parallels with the chaste woman's commitment to one husband only, that loyalism gained later, particularly during the traumatic transition from Ming to Qing.

Dai Liang served for a time as headmaster of an academy in Pujiang, and when Zhu Yuanzhang's troops established control over Jinhua prefecture in 1358, Dai Liang briefly served in the Jinhua prefectural school. ${ }^{15}$ His connection with Zhu Yuanzhang did not last long, however, and from 1361 onwards, Dai rejected the emergent Ming government, maintaining his loyalty to the Yuan. This decision had far-reaching consequences; he tore himself away from the circle of Jinhua intellectuals that had surrounded him all his life, and embarked upon the lonely pursuit of the life of a hermit. It was a departure from the path chosen by the vast majority of his fellow Jinhua men, whose close ties to the first emperor of the Ming are well-known. ${ }^{16}$ The men from Jinhua had provided him until then with a strong community of fellow-minded intellectuals, and had inspired in him strong feelings of a local, Pujiang, identity. ${ }^{17}$

Despite this divergence of political choices, Dai Liang's contacts with fellow Jinhua men like Song Lian 宋濂 (1310-1381) and Wang Wei王禕 (1323-74) remained, as 
is testified in their prefaces to Dai Liang's literary collection, but he refused to follow them in their support for Zhu Yuanzhang's regime, and regretfully, he left his native area. ${ }^{18}$ He spent some of these years living and writing in the Siming 四明mountains in Ningbo, even travelling by boat from Ningbo to Shandong to join the regional government of pro-Yuan militarist Kökö Temür (Kuokuo tiemu’er 擴廓帖木兒,?1375). ${ }^{19}$ Zhu Yuanzhang continued to try to enlist Dai in his service, but to no avail, and in 1383, Dai Liang died a famous, if isolated Yuan loyalist. ${ }^{20}$

The second man was known as Ding Henian 丁鶴年 (1335-1424). Ding had a

Central Asian background, but both his father and his grandfather served the Yuan government. Ding's father served for a time in Wuchang武昌 in Huguang, where Henian and his four brothers grew up. When his father died in 1346, Ding spent three years in mourning, dedicating himself to the study of the Classics, apparently under the capable guidance of his older sister, Yue'e月娥. The arrival of soldiers in the area forced Ding to flee Wuchang, and he ended up, for a time at least, in the Siming mountains. He died at the great age of nearly ninety, and was buried in the Muslim cemetery in Hangzhou. ${ }^{21}$

The third man was Wu Sidao烏斯道 (fl. 1376-80), a man of moderate family background, born in Cixi 慈奚county in Zhejiang. His teacher in his younger days was the monk Zushan 袒闡who also came from Cixi. ${ }^{22}$ Wu initially made a name for himself as a literary figure, and later, after a recommendation secured him a local government post in a Jiangxi county, he also gained a reputation as a benevolent magistrate. ${ }^{23}$ 
These three men formed very different relationships. Dai Liang and Ding Henian became friends in Siming. Dai Liang arrived there around 1368, determined not to serve Zhu Yuanzhang; Ding Henian by then had already been there for two years. ${ }^{24}$ We know that Ding Henian left the area for Wuchang in 1379, and that Dai Liang died in 1383, but it would seem that for the decade or so between 1368 and 1379, the two men became extremely close. They shared their loyalty and commitment to the Yuan, as well as the bitterness and hardship of their lives as exiles. The poems, prefaces, and letters they exchanged testify to the bond between them, and allow us to gain insight into the textual manifestation of that relationship. Wu Sidao was born in the same area, and lived in Siming until 1376, when he set off for his county magistrate posting in Yongxin county in Jiangxi. Wu Sidao and Ding Henian knew each other in Siming and kept in touch, even after Wu Sidao had left for Jiangxi, and Ding Henian had returned to Wuchang. Joseph Lam writes that "a male bonding can only occur when the participants have something, such as music, to share or do together," and that men relate more easily to each other, "the more the participants of a male bonding are similar in one or more ways." ${ }^{25}$ Clearly Dai, Ding, and Wu found common ground between them. They were all of the scholar-official class, and they formed connections of an intellectual, rather than aesthetic or erotic nature, in contrast to some of Joseph Lam's case studies. Rather than being based on similarities, however, the relationships between these men were formed despite the obvious differences between them. While they remained separated by, for example, the ethnic divide between Han Chinese and members of the Central Asian diaspora, or by the political divide between those who chose to serve the Ming and those who refused, or by the regional distinctions between men from different parts of the 
country, these men knew and admired each other. The literary writings exchanged between these three men, in so far as we have access to them today, will form the basis of my analysis. ${ }^{26}$

\section{Friendship and Ethnic Differences}

We know a little bit more about Ding Henian than I have already outlined above, but not a great deal more. Ding's ancestors hailed from Central Asia, with a great-grandfather coming to China as a merchant under Khubilai Khan in the late thirteenth century. Ding's grandfather, 'Sams-'d-Din, served as daruhachi (overseer) in Jiangxi, and his father, a man named Jamal al-Din, served in Huguang. ${ }^{27}$ The modern scholar Chen Yuan 陳垣 carefully analysed the available sources, and ascertained that Ding, who merely identified himself as "Henian of Xiyu," was indeed, as Chen put it, "a member of an important family of the Moslem faith." 28 Nevertheless, the two most informative and most readily available biographical sources for Ding Henian, namely "Biography of a lofty gentleman" (Gaoshi zhuan 高士傳) composed between 1368 and 1383 by Dai Liang, and “Biography of filial son Ding” (Ding Xiaozi zhuan丁孝子傳), composed after 1379 by Wu Sidao, stress his identity as a Confucian gentleman. ${ }^{29}$ The identity of the socalled semuren色目人 was legally and institutionally distinct from the Mongols, from the residents of the Northern territories known as Hanren漢人, and from the Han-Chinese residents of the Southern Song territories known as Nanren南人, although by the 
fourteenth century many semu were educated in Chinese. ${ }^{30}$ A close reading of these two biographies reveals friendships that are built on shared cultural ideals. The cultural ideals that unify these men do not extinguish the ethnic differences between them, on the contrary, the ethnic differences that might have separated them serve to strengthen and lend support to the powerful appeal and resilience of these cultural values.

To begin with Dai Liang's Gaoshi zhuan, the reader initially has no indication that the 'lofty gentleman' (gaoshi 高士) that forms the subject of the biography is anything other than a Confucian gentleman. The very first line immediately clarifies Dai Liang's use of the term gaoshi: "Alas! One so rarely encounters a scholar of lofty integrity (gaojie zhi shi 高節之士)!”31 The locus classicus for the term gaoshi is interesting; it is used in the Mozi, where a gaoshi is defined as someone who treats his friend's person (shen身) as if it were his own, and his friend's relatives as if they were his own. ${ }^{32}$ The term can also refer to a hermit, a man who has chosen not to serve in government. Dai Liang's reference to Ding Henian as a 'lofty gentleman' (gaoshi) appears throughout Dai's writings and forms a key to the relationship, encompassing both the sense of a close friend and the lofty integrity of the hermit. For Dai Liang, Ding is the kind of friend who would treat the wife and children of his friend exactly as he would his own wife and children, as we see in this revealing anecdote: “Vice-Director Ma Ziying馬

子英, who never randomly recommended others, once said: 'I have many friends. But there is only one person, namely Henian, to whom I would entrust my wife and children." ${ }^{, 33}$ But Ding is also the lofty gentleman who chose to spend his old age 
withdrawn from society (shuainian bidi 衰年避地), living “in remote places” (hengmen zhi xia 衡門之下). ${ }^{34}$

To return to Dai's Gaoshi zhuan, the prologue continues with two lengthy quotations, one from the Book of Changes 易經 about the way of the gentleman (junzi zhi dao 君子之道) and one from the Lunyu論語about the Way of the Mean (zhongyong zhi dao中庸之道). ${ }^{35}$ Both illustrate the values associated with the junzi, values hard to attain and maintain at difficult times, explaining the rare occurrence of scholars of such high standards as Ding Henian. If the Book of Changes and the Lunyu are there to provide a certain, obviously Confucian, standard, then Ding Henian clearly measures up to it.

Up to this point in the text, Dai has provided no further information about his subject, but his next sentence, the start of the biography proper, leaves no doubt over his background: “Henian was a man from the Western Regions” (Henian xi yu ren ye 鶴年西 域人也). ${ }^{36}$ Suddenly, the fact that the generation of his great-grandfather had already left that part of the world is not relevant anymore; even though Ding Henian was born and raised in Wuchang, he was a man 'from the Western Regions.' His Central Asian background is emphasized by the inclusion of the exotic-sounding transcriptions of the names of the great-grandfather and his younger brother, the grandfather, and the father. An interesting bit of background is provided about the great-grandfather, A-la-bu-dan阿

喇卜丹: 
At that time, the ancestral emperor (zu huangdi 祖皇帝, i.e. Khubilai, r. 1260-1295)

was seeking land in the West (xun di xi tu 徇地西土). The army had run out of

provisions, whereupon he [i.e. the great-grandfather] rode to the military headquarters and offered them his own supplies. ... As a reward [the emperor] bestowed him with an office. ${ }^{37}$

A-la-bu-dan considered himself too old to take up the invitation to serve, but his son and his grandson would both go on to serve as daruhachi. The elaborately transcribed names and the atmosphere of military campaigns in the remote west conjured up in this anecdote clearly work to enhance the identity of Ding Henian as "a man from the Western Regions," in fact, as "other," as non-Han.

Despite that identity as "other," or perhaps because of it, Dai Liang cites anecdotal evidence that counters that otherness. So we learn that the father, when his tenure as Wuchang daruhachi came to an end, was invited by the locals to make Wuchang his “Tongxiang” 桐鄉, after the Han dynasty governor of Tongxiang, who ruled the area so well that the locals built a shrine in his honor afterwards. ${ }^{38}$ And we learn that when Mr. Wuchang武昌公, as he came to be known, died, his son Henian adopted Chinese rather than Islamic mourning practices:

It was their custom to have only a short period of mourning, wine being the sole item prohibited. Henian took this to be not the ancient practice ( $g u$ zhi古制); so he continued in mourning clothes for three years. He did not drink wine for eight years. ${ }^{39}$ 
Dai Liang clearly does not try to hide the semu identity of the subject of his biography, but at the same time, he is signalling to his reader that when we come to measure this man, it should be along a familiar, i.e. Confucian, yardstick, rather than a Central Asian one. It was, as Dai tells us, Henian's own desire: "I wish to do my utmost to become a Confucian scholar" (wu yu fen shen wei rusheng吾欲奮身為儒生) ${ }^{40}$ By all accounts, he succeeded, as the rest of the biography testifies. Henian was respected by the locally resident scholars (zhuru諸儒), one of whom, a scholar from Jiangxi, even wished to take him home and marry him to his daughter. Although we do not know exactly in which year Dai Liang wrote Ding's biography, we do know that Ding read the biography Dai had written for him. In response, Ding composed a set of four poems and sent them to Dai Liang, carefully indicating that these were written "for the gentleman who once wrote my biography” (xiansheng chang wei zi zuo zhuan先生嘗為子作傳). ${ }^{41}$ The reference to Ding as exemplar of the lofty gentleman appears not only throughout Dai's works, but also Ding's writings, and clearly, Ding endorsed Dai's image of himself as the scholarly gentleman with lofty integrity portrayed in the biography. ${ }^{42}$

When Wu Sidao, the third of the three men of my title, came across Ding Henian, he, too, was struck by the combination of Ding Henian's ethnic difference and cultural likeness. Wu wrote a biography of Ding Henian, significantly entitled "Biography of filial son Ding (Ding Xiaozi zhuan 丁孝子傳)." ${ }^{43}$ Wu's intentions are clear: here is the biography of a man known for his filiality. The story narrated by $\mathrm{Wu}$ in this biography is a moving one: Ding was the son of his father's concubine, née Feng馮, of whom he 
became separated when Wuchang came under attack in 1352. More than twenty-five years later, when he was living in a retreat in the Siming mountains in Zhejiang, Ding returned to Wuchang to find the grave of his mother. He searched for months without success, but eventually a dream led him to the right place. He found a depression in the land, where indeed her bones had been buried, without a coffin but covered with some wooden planks. He reburied her remains in a coffin, built a cottage nearby, and lived there until the end of his life. Clearly the main focus of the biography is Ding's embodiment of filiality. He performs his duties as son well beyond what could be expected of him, and thereby serves as an inspiration for others. As we saw in Gaoshi zhuan, however, the creation of a Confucian identity in the text is built on Ding's identity as 'other.' Here, too, Ding is introduced as 'a man from the Western regions' (Xiyu ren 西域人). ${ }^{44}$ Again the names of father and grandfather are given, in a slightly different transcription: A-lao-ding阿老丁 and Zhi-ma-lu-ding職馬祿丁, underscoring Ding's heritage.

The clearest indication of the otherness of the family background is the description of the original burial site where his mother had been laid to rest. It is a rather gruesome tale:

[Henian] found a flat bit of soil that was sunken. Henian thought to himself: 'I did hear that when my mother was buried, she was not given a coffin. They put down some earthen bricks, and covered her with the planks of an [old] ship. When human remains and planks decompose, then [the level of the soil would drop down] in this manner.' At this point he was almost able to open up [the 
grave] and look inside. He laid out wine and meat as offerings, and when his sacrifice was finished, he opened up the grave. Indeed, he saw that the planks still had their pine knots, and the earthen bricks were also still intact. This he thought very good. Fearing that there might be other graves at this same site, he bit [himself] to draw blood over the bones to provide proof. After a while he wiped it away, and found that the bloodied bone throughout had changed to the colour of madder, and this he could use as evidence [that these bones belonged to his mother]. His mother had one tooth still in her face as if it had been lacquered. Seeing this, he had even more evidence. ${ }^{45}$

Wu Sidao's point here, of course, is to show the extent to which Henian actually practiced the traditions he had made his own: his sacrifice of wine and meat, his smearing of blood on the bones, and his reburial of her bones in a coffin are all important Chinese rather than Muslim practices. Despite that, the image of the dutiful Confucian son is projected onto the image of the concubine of a Muslim man, buried quickly, placed onto some bricks and under discarded, knotted pine planks, a practice perhaps not unknown but certainly strange to $\mathrm{Wu}$ Sidao. It seems to me that the man conjured up in Dai Liang and Wu Sidao's accounts is, indeed, a man well-versed in Confucian practices but a Central Asian nevertheless. These accounts perhaps get us no closer to how Ding Henian saw himself, but they do point at a friendship established across what is constructed as cultural difference, whether we call that an 'ethnic' difference or not.

Of course Ding Henian was not the only Muslim who adopted Confucian practices and was respected for his cultural values by southerners (Nanren). Men like Yu Que余關 (1303-58), a Tangut official and local reformer under the Yuan, Sa-du-la薩都刺, 
referred to by Dai as Sa Tianxi薩天錫(1308-1388), also a semu, and Ma Zuchang馬祖常 (1279-1388), an Önggüd, all wrote poetry in Chinese, and Dai Liang appreciated their familiarity with "the Middle Kingdom" ${ }^{46}$ Dai saw their ability to write poetry as evidence of the great transformative powers of our dynasty (wo chao wang hua我朝王 化). ${ }^{47}$ Dai's relationship with the Muslim Ding Henian was not exceptional among the social contacts Dai maintained; Dai especially admired Yu Que, and was deeply moved by Yu's death in 1358 in one of the by then so common local attacks by rebel bands. ${ }^{48}$ But throughout his writings, Dai refers to these men only sporadically, and never exchanged personal writings or developed intimate bonds. The admiration of $\mathrm{Wu}$ for Ding, and especially the friendship between Dai and Ding, constructed over the ethnic differences between them, is significant for its depth of feeling. Ethnicity mattered, but did not prevent the development of a bond. Similarly, the different political choices they made mattered. As we will see, the bond between Dai and Ding was clearly strengthened by the political choice, loyalty to the Yuan, they had both made.

\section{Friendship and Political Difference}

To evaluate the political choices these three men made in the face of Yuan collapse and Ming establishment, we need, briefly, to reflect on the relevant context of regime change and loyalty as witnessed during the loss of the North to the Jurchen in 1127, the end of Jin rule in 1234 , and the end of the existence of the Song regime in $1276 .{ }^{49}$ The traumas associated with the loss of the north in 1127 have been well documented, but of course the loss of the north was to some extent compensated by the preservation of Song rule, albeit in truncated form, in the south, where "most leading literati families" moved. ${ }^{50}$ 
Nevertheless, large numbers of literati also remained in the north, and maintained their identities under Jurchen rule. ${ }^{51}$ The Jin clearly commanded loyalty—as Franke writes, "there were defectors and opportunist, but a surprisingly great number of leaders and soldiers, Jurchen and Chinese alike, remained faithful to the bitter end." ${ }^{, 52}$ That loyalty does not, however, seem to have translated in the performance of Jin loyalist practices by Chinese literati once Jin rule had fallen. For that, Jin rule had been too brutally established and too short-lived.

The end of Song rule, however, did engender widespread loyalist sentiments. The battle against the Mongols was hard-fought, a great many people lost their lives, and many literati mourned the loss of their dynasty. Richard L. Davis' eloquent discussions of Song loyalism in Wind Against the Mountain, and the famous heroics of resisters against Mongol rule such as Wen Tianxiang文天祥 (1236-1283), have brought Song loyalism to the forefront of our minds. ${ }^{53}$ Other, more recent research, however, suggests that we have to be careful in our assessment of Song loyalism. As the excellent studies by Jennifer Jay and others have demonstrated, representations of Song loyalism have been shaped to some extent by later authors, who turned biographies into hagiographies, and created myths of widespread resistance, to suit their own agendas. On the whole, Jay contends, "loyalist martyrdom was atypical of the overall Song response." ${ }^{54}$ The breakdown of Song rule and the establishment of a Mongol regime, once seen as major disruptions in the narrative of Chinese history, have more recently taken on the more gentle guise of a "Song-Yuan transition," the social transformations of the period more associated with the end of Northern Song activist and centralist state policies and the start of the "localist turn," than with the invasion of Mongols in Han-Chinese territory. ${ }^{55}$ 
Song loyalism was more a sentiment than a code of practice, and more an intellectual ideal than a matter of life and death. As such, it was very different from the loyalist sentiments expressed by literati after the fall of Ming rule in $1644 .{ }^{56}$ Relatively quickly, those who saw themselves as Song loyalists took on posts in the Yuan government, or at least encouraged their sons to do so. ${ }^{57}$ Even students of famous Song loyalists accepted posts under Yuan rule. ${ }^{58}$ Those who saw themselves as "left-over subjects" of the Song (yi min遺民) soon recognised that they could, for all intents and purposes, combine Song loyalism with Yuan subjecthood. None of the literati who had lived through the collapse of Song rule and the establishment of the Yuan regime in 1276 were still alive when Zhu Yuanzhang created his Ming state in 1368, although their ideals had been transmitted. ${ }^{59}$ It was most likely the continuity of Song loyalist ideals, combined with the ideal of loyalty to one regime that inspired loyalists to the Yuan like Dai Liang. ${ }^{60}$ Dai Liang was not alone; Yang Weizhen楊維楨 (1296-1370) considered himself to be a Yuan loyalist, as did Tao Zongyi陶宗儀 (ca. 1316-ca. 1402). ${ }^{61}$ But Dai Liang was one of very few southern Chinese men to refuse all Zhu Yuanzhang's advances, and certainly an exception in Jinhua. It made Dai feel, to a certain extent, a lonely, isolated man. ${ }^{62}$

The choice by Dai Liang and Ding Henian to stay loyal to the Yuan government, and to refuse to entertain any substantial contacts with Zhu Yuanzhang, takes on a greater significance in this context. The bond between these men was surely strengthened by this shared loyalty. Indeed, the many texts these two men exchanged testify to the strength of feeling between them. For Dai Liang, Ding Henian exemplified the cultural ideal of a gentleman who rates scholarly pursuits and learning more highly than rewards and social 
standing. In Dai Liang's eyes, Ding was like the poet Tao Yuanming 陶淵明 (365-427), who preferred a life of solitude and farmwork over a meaningless administrative posting. ${ }^{63}$ Dai made the comparison of Ding with Tao Yuanming explicit in several of the texts they exchanged. Dai sent Ding a set of seven poems composed after Tao Yuanming's famous series of seven poems "Ode to the impoverished scholar" (Yong pinsh qishou 詠貧士七首), expressing their “shared ambitions” (tongzhi同志). ${ }^{64}$ Dai also composed a fu (賦) for Ding Henian in which he vividly described Ding's solitary existence in the vocabulary of Tao Yuanming: Approaching old age, he lived a humble life among lakes and rivers, ${ }^{65}$ Living as a hermit in the wilderness, he rarely welcomed guests.

His feelings were the same as Tao Yuanming's from Lili, His appearance resembled Ding Lingwei from Liaodong. ${ }^{66}$ 投老江湖生事微, 隱身草澤接交稀. 情同栗里陶彭澤, 形似遼東丁令威.

The poem ends with a stanza that describes the depth of their shared feelings:

Living in the wilderness east of the walls, ${ }^{67}$ I share the same bitterness, How many times have we visited each other, talking into the evening's light? ${ }^{68}$ 牆東野客心同苦, 幾度相從話夕暉.

Poems like these, exchanged between these two men, reveal the depth of the anxiety over their political choices. Like in Tao Yuanming's experience, the choice is between serving and reclusion, but also between losing or preserving one's integrity. ${ }^{69}$ The 
ongoing hardship and real danger that were the inevitable result of the choice Ding and Dai both made was something that brought these two men closely together.

Wu Sidao, on the other hand, gratefully accepted the opportunity to serve Zhu when it was offered to him upon his recommendation. ${ }^{70} \mathrm{Wu}$ Sidao's initial experience of government occurred during the late Yuan, at the local level, in his native county Cixi. As John Dardess has shown in his 1982 study of late Yuan local reform in Zhejiang, Wu was part of a group of local "advisers" to the Cixi magistrate, who instigated a number of important fiscal, social, and moral reforms under their guidance. This group, which included not just Wu Sidao and his brother, but also a descendant of one of Lu Jiuyuan's 陸九淵 (1139-93) disciples and a descendant of the Song imperial house, was bound together by their interest in political theories and activist local policies. Under the instructions of the group, the Cixi magistrate implemented not just fiscal reforms, but also organizational reforms aimed at a reduction of the power of clerks and an increase of impartial contributions from all levels of society. They even offered helpful tips to the magistrate such as placing a sealed "suggestions box" in the county school, and wearing a "stern expression" when consulting the clerks. ${ }^{71}$ The "reform era" in Cixi came to an end when the area came under attack in 1358, and the Cixi magistrate surrendered to Fang Guozhen方國珍 (1319-74), who competed with Zhang Shicheng張士誠 (1321-67) and Zhu Yuanzhang for control over this area until he was defeated by the future Ming founder. ${ }^{72}$ When Wu Sidao went to Yongxin to take the post of county magistrate in 1376, these earlier experiences of local government may well have informed his own practices. 
Interestingly, when $\mathrm{Wu}$ Sidao wrote a piece about Dai Liang, that political difference remains entirely undiscussed. What does emerge, however, is the regional difference between the two men. Wu Sidao records a conversation he once had with Dai Liang when his friend came to show him a picture of his house in the Jiuling Mountains. "What is the reason for you showing me this?" asked Wu. ${ }^{73}$ The answer, dutifully recorded by $\mathrm{Wu}$, is a lovingly told description of Dai Liang's native Pujiang, and specifically the remote Jiuling Mountains where the Dai family had their home. ${ }^{74}$ Dai conjures up a vivid image of soaring mountains covered with "different types of pine, bamboo, plum and cassia trees," where even those who have the benefit of walking sticks and sandals are not spared some physical distress in their ascent. ${ }^{75}$ It is not merely the scenic beauty that moves Dai, but also the emotional bonds that tie him to this place: The gravemounds of my ancestors, and my father and brothers are all there. I, however, have travelled across the rivers and stayed in the lands of Qi齊 and $\mathrm{Lu}$

魯. When the military troubles occurred I crossed the great sea, and went east to Siming. ... For a long time now I have thought about returning to my old cottage, to see the mulberry trees, sweep the gravemounds, make peace with my father and brothers, and bring the younger generation together when they have free time from their studies. [I want to] pick flowers in the mountains and fish in the rivers, to roam around and sing to the end of my days. ${ }^{76}$

The references to the military troubles and Dai's journey across the sea are interesting. We know that Dai had left Pujiang when the area came under attack in 1357, and that, although he briefly served Zhu Yuanzhang when the latter had taken Jinhua prefecture in 
1358, he spent the following years more or less in hiding. He spent time in Suzhou, Ningbo, Shandong, in the Siming mountains in Zhejiang, and finally in Nanjing, where he died. His decision not to return to Pujiang must have been largely driven by political motivations; he clearly chose not to be associated with the activist thinkers from his native Jinhua who became so closely involved with Zhu's Ming regime. ${ }^{77}$ Thus he spends his days longingly looking at his pictures of the Jiuling Mountains that hang in his bedroom without ever going home.

It is precisely in the political choice that lies at the heart of these emotions that the difference between Dai and Wu is located. Dai has chosen to distance himself from the political connections between his hometown and the new regime, willingly suffering the pain of exile. Wu has made different choices; he left his home behind to serve in Zhu Yuanzhang's new state structure, taking with him his Cixi experiences in local governing. Their friendship exists in the face of those differences. As we saw in the case of ethnic difference, these men are connected through a bond based on shared cultural values that allows for political difference. Wu does not try to hide the difference in their political choices:

Since the gentleman has a good grasp on the Way and is broadminded, he surely knows that heaven, earth and the myriad things are all contained within the self. The Jiuling Mountains go with him wherever he resides. Why should they need to be fixed to one place, as if coated in lacquer? ${ }^{78}$

By suggesting to Dai that he is "broadminded," accepting the immanence of all things, $\mathrm{Wu}$ is indirectly encouraging Dai to let go of his attachment to the old regime. Moral values are located within the self, and remain so regardless of the political regime. The 
meaning of the Jiuling Mountains painting-Dai's attachment to his old home as well as the moral values that his old home represent to him — is not lost when he moves on, but is contained within the self. Just so, Wu suggests, when he switches his loyalty to the new, Ming, government.

The sentiment is echoed in two poems sent by Wu to Ding Henian at the time of Ding's return to Wuchang in search of his mother's grave. Wu's poems are inspired by two noteworthy sites in Wuchang: one the summer residence of Sun Quan 孫權 (182-

252), who proclaimed himself the ruler of $\mathrm{Wu}$ 吳 in Wuchang in 229, the other the library

(dushu tang 讀書堂) built by military leader Tao Kan 陶㑆 (259-334). In an afterword,

Wu explains the significance of the latter building: it was located in the mountains not far from Wuchang, near the site where Tao Kan found a copper Guanyin on the sand, after which it became a Buddhist temple. After that had fallen into disrepair, Ding Henian's father was buried here, and Henian built a small hut by its side. Wu's poem reveals some of his responses to Ding's decision to return to Wuchang:

You travelled up the Yangzi suddenly to return home, To precisely this place where heroes read their books. The myriad spirits rush about, protecting your father's grave, yet you built a thatched hut near the lofty trees.

君溯長江忽歸去，政是英雄讀書處。百靈奔走護先丘，就結茅堂倚高樹。79

Ding is travelling against the current, not just of the river, but of society; while everyone else is lending their support to the government, as indeed Sun Quan and Tao Kan had 
done, Ding is physically and spiritually turning away from society. Wu seems bewildered by Ding's choice, unable quite to share Ding's desire to cut himself off from their life in Siming:

You stay there, among lofty clouds, withdrawn from official life, As before leisurely composing poetry.

Throughout history, both those frustrated and successful in life have cherished the same styles.

There is no need to be ashamed before our ancestors, your face all red.

\section{且訪雲間入林下，依舊從容詠風雅。古今窮達貴同風，莫愧前人面如赫。 80}

It is an implicit critique of Ding's choice to remain loyal to the old, without exploring fully what $\mathrm{Wu}$ Sidao has decided is the same moral backbone of the Ming government, the new. As he writes at the end of the first poem:

You have chosen to return home to visit to retrace your steps, do not bemoan that of old, fortunes rise and fall.

君今歸去訪遺跡，自古興亡休嘆息。 ${ }^{81}$

Ding's return home is like a slap in the face to $\mathrm{Wu}$ : by retracing his steps he is walking away from the Ming government and the promise it holds out. Wu, the pragmatist, has already switched loyalties, and would like Ding to do the same. Ding's response, however, is clear in its refusal to bend:

Clutching my stick, I sigh in my daily activities, My heart longing for the distant past.

扶杖日行吟, 悠然太古心. ${ }^{82}$ 
The poem Ding sent to $\mathrm{Wu}$ Sidao seeks to appeal to the heritage they both share, the Odes and “this culture of ours” (大雅消沉久, 斯文感慨深). ${ }^{83}$ The sadness caused by their loss, as Ding sees it, is what motivates his refusal to bow to political demands, while Wu stresses the precedent for the choice he has made. The political difference is undoubtedly relevant, and the cause of a certain distance between the two men. Nevertheless, what keeps the men together is the shared territory between them: the styles they both cherished (gui tongfeng貴同風). Despite the difference in political interpretation, the shared appreciation of poetic compositions and styles is what united these men and nourished the bond between them.

From the biographical descriptions these men wrote for each other, then, it would seem that they themselves regarded their relationships and their similarities as stronger than whatever political, ethnic, or regional difference we as outside observers might recognise between them. Or, put in a slightly different way, these three men created for posterity a record of friendships that cancelled out social, political and ethnic difference. Formulating it in this way suggests that somehow this friendship was a construction, a representation. With the paucity of sources available, we venture out on slightly thin ice with that statement. Nevertheless, I suggest that reading the record of their friendship in this way is helpful, because it forces us to ask an important question: Why is it that the relationships between these three men constructed in this way?

\section{Gendered Readings}


To understand why the friendship between these men is constructed as a social connection that is more significant than, say, the bond shared between men of semu status, or between men who had made similar political choices, we need to take account of the gendered nature of these relationships. I will argue that friendship connections between late Yuan and early Ming men created a space where alternative masculinities could be established and developed. ${ }^{84}$ To illustrate this, we need to take a brief look at the social and cultural spaces within which masculinities were negotiated in Yuan and early Ming China. One could argue that participation in the examination system was one of the ways in which men could 'perform' their masculinity. ${ }^{85}$ As a pathway through life it was exclusively available to men, and therefore presented straightforward opportunities not only for signalling masculinity to the wider world, but also for creating lasting bonds with other men. ${ }^{86}$ For much of the Yuan dynasty, however, the examinations were suspended, and when they were reinstated in 1315 , the quotas were weighted heavily in favor of men with Mongol or semu classifications. ${ }^{87}$ It had, thus, become much harder during the Yuan dynasty to use participation in the examination system as an expression of masculinity and a domain for male bonding. Similarly, appointment in the state civil service, once the most obvious goal to aim for, and a significant arena for the development and performance of male friendships, was heavily restricted. During the Yuan dynasty, Han men, as others have pointed out, had far fewer options open to them in terms of their careers and their public roles. As Robert Hymes and Peter Bol have pointed out, during the Southern Song and Yuan dynasties, literati largely turned away from the central government, and turned their attention to local networks. ${ }^{88}$ Han men of 
the Yuan dynasty often found alternative modes of employment; they became private tutors, heads of academies and schools, members of poetry circles, and doctors. ${ }^{89}$

For those men who chose to stay loyal to the Yuan after the fall of its government, that situation continued during the early years of Ming rule. Dai Liang wrote approvingly of the wide-ranging activities of his friend Ding, who had refused all invitations to serve. "He remained at Siming, for a time eking out a living in a small place by the sea tutoring children, and for a time staying at a Buddhist monastery, selling medicines to provide for himself." ${ }^{90}$ The admiration he feels for his friend is based in part on the way in which he personally engages with this wide range of practical solutions for daily life:

Henian is very intelligent. If he just passes his eyes over something he is reading, he can recite it perfectly. He is good at writing poetry, and particularly skilled at regulated verse in the style of the Tang. His prose writing has vitality, and he is well-versed in the theories of mathematics, breathing exercises, and herbal medicine, especially because his learning is based on personal practical action. ${ }^{91}$ If one of the main avenues for the performance of manhood, namely the civil service examinations and official service, was closed off during this time, then other avenues had opened up. Dai conjures up an image here of a man of non-Han background, who found other ways of being, and perfected those too. In the friendship that was given concrete form in the biography written by Dai for Ding when Ding was still alive, Dai creates a space for Ding not only to be a man in alternate ways to the traditional pathways of examinations and government, but to perform that role in a superior way. The bond between the two men serves to endorse these alternate ways of being a man. In their writings, they signalled their status as gentlemen both to each other and to the wider 
world.

In these exchanges between men, however, it remains difficult to see how gender difference is constructed and understood during the Yuan-Ming transition. For this we need to look more closely at the encounters between male and female. ${ }^{92}$ Martin Huang's recent book, Negotiating Masculinities in Late Imperial China (2006) reveals the extent to which male gender identities were negotiated through writing about gender and the role of women in society. ${ }^{93}$ As it happens, all three men, Dai, Ding and $\mathrm{Wu}$, wrote about women. As Beverly Bossler has recently pointed out in an important piece entitled "Gender and Empire: A View from Yuan China," this was in fact not unusual. ${ }^{94}$ As she writes, "texts honoring faithful women became a popular form of literati discourse in the Yuan."95 As Bossler demonstrates, from the mid-twelfth century onwards, when Song China came under attack first from the Jurchen and later from the Mongols, men display increasing enthusiasm for writing narratives of loyal women resisting the invasion of their bodies, their moral integrity mirroring loyal military officials' defence of territorial boundaries. Writing biographies or poems about faithful wives and heroic women, Bossler shows, increased dramatically during the Yuan. ${ }^{96}$ One of the reasons why faithful wives inspired poetry in male writers is, she suggests, its social function. ${ }^{97}$ She sees the exchange of writings about faithful wives and loyal women between men as ways to "assert and affirm personal social networks." 98 It is this final assertion I would like to examine a little more closely in the context of the writings exchanged between Dai Liang, Ding Henian, and Wu Sidao.

Indeed, all three men wrote about faithful wives and loyal women. ${ }^{99}$ One of the women they shared an interest in was the older sister of Ding Henian, a woman known as 
Yue'e (before 1335-1360). Yue'e would enter official history by featuring in the first listed biography in the chapter on women in the Mingshi, but that very brief biography was almost entirely based on the much fuller account of her life written by Wu Sidao. ${ }^{100}$ From his account we learn that Yue'e had gained her education along with her brothers in the household, and had shown great aptitude for learning from an early age. She married a certain Ge Tongfu葛通甫 (fl. 1360), a man from Wuhu無湖 in Taiping太平 prefecture. $^{101}$

After she had arrived in his family, she served her elders and cared for the young, strictly following the ritual prescriptions. The senior female, [a woman named] Lu盧, regarded the virtue of Yue'e even greater than her own. One day she addressed the wives and daughters: 'I would like you wives and daughters to be taught. You have never received any instruction.' Yue'e accepted her order. Since they only humbly partook of pastimes like sewing and needlework, she had to teach them the Way of Women (fu dao 婦道), so she drew on the [examples of] martyred women of old (gu lie nü古烈女) to illustrate [the Way of Women] to them. All of them were transformed under her guidance. ${ }^{102}$

Once again, like in the biography he wrote for her younger brother, Wu Sidao expresses his full admiration for the way in which this woman of Western Asian descent not only mastered moral instruction and Classical learning, but also transmitted her learning to the women in her husband's family, probably using the old stalwart of female moral instruction, the Lienüzhuan 列女傳. 
While she used the exemplary lives of women to enlighten the wives and girls in her new family, she would herself go on to became a moral example. When the area came under attack from roaming bandits, the women in the family sought refuge inside the city walls.

Yue'e sighed: 'I was born in a family of generations of officials [lit. cap-clasps and sashes]. Would they have suffered at the hands of dogs and pigs?' So she clutched the girl she had borne and drowned herself in the river. The other wives and daughter were all shocked. They exclaimed: 'Our tutor's death has ensured she is at peace with rightness. Can we now ever live happily?' So they followed her to their deaths in the river. None of these nine had any offspring. ... At the time of their deaths the heat of the summer was most intense, and for seven days they did not sprinkle water on them, yet the color of their faces was as if they were still alive. All of the locals marvelled at this. ${ }^{103}$

The ten women were buried together, and a stone was placed by their grave with the inscription 'Grave of Ten Martyrs'十節墓. Her brother Henian finally placed a wooden plaque by the grave with in inscription telling of their heroic deed.

Strikingly, the text reveals close parallels with another description of a martyred woman in Wu Sidao's writings: the record of the shrine for Lady Tan. Wu Sidao had come across the dilapidated shrine for Lady Tan on his first tour of Yongxin, immediately upon his arrival there as magistrate in 1376. He had restored the building and composed a text. This is his description of her death a hundred years earlier, at the hands of Mongol soldiers in 1277: 
The northern army suddenly entered the city, and great chaos in the city ensued. The people all grabbed their belongings and fled. The woman [i.e. Lady Tan] held the child she was nursing and together with her parents-in-law quickly ran to the Hall of the Sages at the County School. Soldiers then arrived there en masse, killing and raping people. This chaste woman was not afraid to resist the soldiers who wanted to rape her. The woman spoke angrily: 'My parents-in-law have been killed by you. I will guard my body with my life, and will not allow you [to do this]. How could I let my body be defiled because of my desire to live?' As she did not give in, the soldiers became angry, and they killed her and her child. ${ }^{104}$

Here too, the women take refuge inside the city walls, but the walls provide no protection, and the soldiers enter their safe haven, as they then seek to invade their bodies. Here too, the woman speaks out in defiance, establishing her superior morals and fighting spirit.

The similarities between the two incidents and the two texts place them in a slightly different perspective. It is not merely one individual case that Wu Sidao is interested in here, but a set of cases. Much of this confirms Bossler's arguments. Here, too, it is literary men who write about women, rather than men known as 'moralists. ${ }^{105}$ They write poems about faithful women, although not exclusively so. And indeed, there is a certain mechanical quality to the writings with their stock phrases that suggests poetry written less 'for other connoisseurs to savor' and more 'to fulfil the obligations of literati social life, ${ }^{, 106}$ although as Bossler herself suggests, gentlemen and scholars also 'savored' the tales of heroic suicides as they wrote, exchanged, and published them. ${ }^{107}$ 
This final thought is worth exploring further. Almost all of the faithful widows and female martyrs $\mathrm{Wu}$ writes about are described in standard phrases: they are intelligent (conghui 聰慧) and introspective or quiet (jingyou 静幽), they take their studies very seriously, and they reveal their high moral calibre as soon as they join their husbands' families. The focus of the narratives then shifts, however, from mind and morals to violence and body. It is as if the wheel suddenly spins, pivoting around the central figure of the marauder as he makes his (physical) entry. This pivotal moment in the first instance creates the impression of a set of binary opposites: between female and male, between civilised (wen) and military (wu), between inside and outside, with the weak city walls that fail to keep the invaders out symbolising China's weakness as it gave up to the various non-Han invaders, between moral and amoral, between human and beast. In the next instance, however, it is clear that these binary opposites fail to capture the complexity of the situation. In the case of Yue'e, for example, the female, the civilised, the insider, is at the same time herself also a non-Chinese, the 'outsider', who has acquired these qualities 'despite' her background. Moreover, the masculine here stands for the brutality of the invader, who forces his way in. Masculinity, in other words, is here based on associations with the military, with the amoral, with the beastlike qualities the women identify in them.

So where does it leave the Han Chinese male reader? His absence from the story is significant in itself, as implicitly the absence of husbands or brothers is what has left these women unprotected and vulnerable. He either identifies himself with the feminine, the woman taking her life to avoid rape, or with the masculine, the marauding invader. The former would be the natural choice, based on a long history of male identification 
with female loyalty, but that identification only serves to highlight the shortcomings of that male reader, who clearly has not had the courage to choose that same moral high ground, and has instead chosen to live. The latter, association with the brutal masculinity of the invader, is clearly problematic, too, not so much because it is inconceivable that there is a titillating dimension behind this focus on bodies, and on the physical and sexual breaking down of barriers, but because it throws masculinity into question. ${ }^{108}$ What does it mean to be a man, and what outwardly acceptable ways of behaving as a man are presented in such tales?

Richard Davis' discussion of masculine behaviour after the fall of the Southern Song suggests that the virility of the nomadic invaders generated a sense of crisis among the Han Chinese in the north and the Nanren in the south. He purports that Han men committed suicide in large numbers, in part to demonstrate their loyalty to the Song, and in part to assert their masculinity in heroic behaviour. ${ }^{109}$ Paul Smith, who takes issue with Davis' views, sees a different male response to Mongol invasion; the diarist Kong Qi 孔齊 (ca. 1310-after 1365) paints a picture of a world where gender roles were subverted, and men lamented their loss of authority and control to usurpatious women. ${ }^{110}$ Dai Liang, loyal to the Yuan, chose not to commit suicide, and neither do his writings betray anxiety over the increasing powers of women. Rather, the writings about women by Dai Liang, Ding Henian and Wu Sidao confirm Bossler's suggestion that for men, moral action was located in the production of texts. Dai Liang clearly had the moral highground when he wrote "The relationship between a woman and her husband is the same as the relationship between a scholar and his ruler: s/he serves only one until the end," but Wu had no compunction in writing about the chastity and suicides of the 
women he admired without any expression of guilt over his own choice to serve more than one government. ${ }^{111}$ Moral acts like committing suicide were the domain of women, while men shared "the production, circulation, and appreciation" of texts about exemplary loyal women. ${ }^{112}$

As we saw in the exchanges of writings about women, through such texts men established and maintained social networks of men. While other avenues of masculinity were perceived to be problematic or even closed off, when traditionally male dominated spaces such as the examinations and civil service examinations were heavily curtailed, friendship during the late Yuan and early Ming years remained an important avenue for the construction and performance of masculinity. Writing about women, furthermore, served not only to cultivate male bonds but also to explore the meanings of masculinity and manhood.

When $\mathrm{Wu}$ Sidao wrote down the conversation he had with Dai Liang about the painting of the Jiuling Mountains in Dai's native Pujiang, Wu sought to affirm the significance of their-male — connection over the differences that might have stood between them. Dai's longing for home stresses his status as a sojourner in Siming, Dai's refusal to go home and join his fellow Jinhua men in their support for Zhu Yuanzhang stresses his status as a political refugee, but in his friendships, or so $\mathrm{Wu}$ seems to want to impress upon Dai, he has something that overcomes those differences. Ding Henian, who did not feature in the conversation between Dai and $\mathrm{Wu}$, inscribed the Jiuling Mountain scroll with a poem of his own, and makes a similar point:

Separated for ten years from the hometown in your dreams, this painting is so life-like, is it real or not? ${ }^{113}$ 
The fresh water in the black pool is refilled when spring returns, the study near the floating clouds by evening appears even loftier. Zhang Han assessed his circumstances, and decided to go home, Guan Ning hid from unrest for so long he forgot to return home. If one understands the significance of being a hermit in a man's life, then the forested mountains are covered everywhere in wild greens.

\section{題九靈山房圖}

\section{夢裡家山十載違; 丹青㓳尺是耶非. 黑池新水春還滿; 書閣浮雲晚更飛. 張翰}

\section{見機先引去; 管寧避亂久忘歸. 人生若解幽樓意; 處處林丘有蕨薇. ${ }^{114}$}

It is a poem about distance, about being exiled from one's home, and about the choices one can make about returning home or not, as Zhang Han張翰 and Guan Ning管寧 did. ${ }^{115}$ The final couplet, however, is the crucial one. In understanding why one chooses to reside in a "hidden building" (youlou 幽樓), i.e. to live the life of a hermit, one has to see that wherever there are mountains, there are "wild greens" to provide sustenance. ${ }^{116}$ It is the universality of place that Ding stresses. As Wu puts it: "The Jiuling Mountains go with him wherever he resides. Why should they need to be fixed to one place?" 117 Both seem to be creating a space for alternatives, where the old constants such as one's home and kinship connections, and implicitly the rank and status that Dai is rejecting by living the life of the hermit, no longer matter. It is within this separate space that morals matter, and where friendship can blossom. It is as if both $\mathrm{Wu}$ Sidao and Ding Henian are reassuring Dai Liang that there is a value in this position, this 'fifth relationship,' despite 
its apparent marginality and despite its potential for threat to the other Confucian relationships. ${ }^{118}$

The issue, thus, is not to create a different set of values, but to create a different space where these shared values can flourish. This also helps to explain the emphasis on friendship overcoming differences, be they political, ethnic, or regional, as we discussed at the beginning of the paper. When Dai Liang and $\mathrm{Wu}$ Sidao write their respective biographies of Ding Henian, they construct a Confucian identity for Ding. They do not ignore his Central Asian background, but their value judgment of Ding rests on his ability to be a Confucian gentleman. It is as a Confucian gentleman that Ding outdoes their other friends, as the only man among Dai's friends to whom he would entrust his wife and children. ${ }^{119}$ In terms of trustworthiness, Ding ranks higher than his other friends, especially in the gender-sensitive task of a man looking after woman and child. In terms of poetry, too, Ding Henian is judged along Chinese cultural standards. In his poetry "the phrases and style are very similar to Du Zimei杜子美 [i.e. Du Fu杜甫, 712-770] while the wording and implied meanings have all benefited from the great poets of our dynasty." As Dai sees it, the men of the far west have all "left behind their bows and horses, studying the Book of Poetry and the Book of History, so that they became known for their poetry in their generation." 121 Precisely because of his Central Asian background, Ding's exemplary role as Confucian gentleman has the power to inspire others. The implied contrast between the two styles of manhood, the Central Asian horseback hunter and the sinified poet is clear, as is Dai's relative judgment of the two. The realm where the cultural differences are greater is decreased in favor of the space where they are the same: men who share an appreciation of poetry and Confucian values. 


\section{Conclusion}

The fourteenth-century terrain that shaped the lives of these three men, Dai Liang, Ding Henian and Wu Sidao, was full of obstacles; their options were limited, and they were confronted with fighting, unrest, and political upheaval. Their backgrounds were very different and the personal and political choices they made were different. Yet in their writings, they created a male bond that sought to overcome these differences. They constructed a friendship based on shared cultural ideals that was more valuable and more powerful than the ethnic, regional and political divisions between them. To understand why this might be the case, I suggested, we have to look at the ways in which gender identities were constructed during this time of fragmented and shifted realities that characterized the Yuan-Ming transition. Men wrote profusely about women during this period, and in particular about loyal women. Men wrote and exchanged descriptions of loyal women that displayed a fascination with the female body, with the violence it encountered, and with the moral values that remained intact when the physical body was destroyed. This occupation with writing about women suggests these men shared a sense of the ideal of femininity: chastity, loyalty, and a disdain for the physical body. From the writings explored here, however, it is much less clear what ideals of masculinity at this time entailed, especially at a time when in the confrontation with the non-Han male, northerners (Hanren) and southerners (Nanren) had fewer options available to them. Women's bodies could be constructed as sites of moral action, but while men's bodies were physically excluded from traditionally male realms such as the examinations and civil service posts, masculinity was far more difficult to define. I have proposed here that 
male friendships offered one answer to this crisis of masculinity: friendship provided a space within which values of masculinity were shared and expressed; friendship between gentlemen created a space within which the fissures of the fourteenth-century terrain were levelled out.

\footnotetext{
${ }^{1}$ I would like to thank Martin Huang for taking the initiative in organising the original AAS panel in which these papers were first presented, and Harriet Zurndorfer for making their publication possible. Martin Huang, Paul Ropp, Peter Ditmanson, Maram Epstein, Beverly Bossler, Bettine Birge and Harriet Zurndorfer all offered extensive and extremely valuable comments on earlier versions, for which I am very grateful. The pertinent views of the anonymous reviewer greatly helped me in reshaping the paper. All remaining errors are, of course, entirely my own responsibility.

${ }^{2}$ This point is not new, of course. This aspect of relations between men has already been made, for example, by Susan Mann. See Susan Mann, "The Male Bond in Chinese History and Culture," American Historical Review 105 (2000):1600-14. Mann suggests that "the family system, the civil service examination system, and patterns of male sojourning," which form the main structures of human action in late imperial China, ensured that men mostly spent their time in all-male environments. Mann, "The Male Bond," 1603.

${ }^{3}$ Joseph McDermott's article, entitled "Friendship and Its Friends in the Late Ming," is one of very few studies that seek to engage with the question of male friendship in Ming China. Joseph McDermott, "The Friendship and Its Friends in the Late Ming,” in Zhongyang yanjiu yuan jindai shi yanjiu suo 中央研究院 近代歷史研究所, ed., Jinshi jiazu yu zhengzhi bijiao lishi lunwen ji 近世家族與政治比較歷史論文
} (Taipei: Zhongyan yanjiu yuan Jindai yanjiu suo, 1992), 67-96. Norman Kutcher also discusses this subject in some depth. See Kutcher, "The Fifth Relationship: Dangerous Friendships in the Confucian Context," American Historical Review 105 (2000):1615-29. The gendered aspect of such relationships and the question of masculinity in Chinese history has, until recently, not been studied as much as it has outside of the China field. One of the first studies was the American Historical Review forum entitled "Gender and 
Manhood in Chinese History" published in 2000. The forum contains two overview studies by Susan Mann and Robert Nye, and three case studies by Norman Kutcher, Adrian Davis, and Lee McIsaac. American Historical Review 105.5 (2000). It was followed by several important studies, such as Kam Louie, Theorising Chinese Masculinity: Society and Gender in China (Cambridge: Cambridge University Press, 2002); the reader edited by Susan Brownell and Jeffrey Wasserstrom, Chinese Femininities/Chinese Masculinities (Berkeley, Los Angeles, London: University of California Press, 2002); Song Geng, The Fragile Scholar: Power and Masculinity in Chinese Culture (Hong Kong: Hong Kong University Press, 2004), and most recently Martin Huang, Negotiating Masculinities in Late Imperial China (Honolulu: Hawai'i University Press, 2006).

${ }^{4}$ One caveat needs to be established at the outset. The extant sources for fourteenth century China are by no means as rich as they are for either earlier or later periods. The understanding of "friendship" I apply in this paper is of necessity somewhat broader than it might be for other periods. For the purposes of this paper, I understand it to mean a relationship between men evidenced in the exchange of writings, although I am acutely aware of the difficulties in understanding "friendship" across such temporal, spatial and cultural distances. In the Western European context, some interesting work on friendship has been done using literary texts. Lorna Hutson, for example, has analysed sixteenth-century English writings to form a picture of a changing meaning of "friendship." She argues that in the English context, friendship may have started out as "a code of faithfulness," a regulatory and economically defined relationship expressed in exchanges of gifts and hospitality, but transformed during the sixteenth century under the influence of humanism and print culture to a relationship generated in the exchange of persuasive writings and rhetoric. See Lorna Hutson, The Usurer's Daughter: Male Friendship and Fictions of Women in Sixteenth-Century England (London: Routledge, 1994).

${ }^{5}$ As will become clear from the discussion below, I am not suggesting that the relationships between these three men were exclusive or exceptional.

${ }^{6}$ For a discussion of the meaning of travel (you遊) for the establishment of social contacts and friendships

(you 友), see the introduction to this issue by Martin Huang. 'Musiking' is the term used by Joseph Lam for the wide variety of meanings, activities and interactions associated with the production and 
consumption of music. See the article by Joseph Lam in this issue. For an excellent introduction to the chaos and disruptions of the fourteenth century, see Paul J. Smith's masterly study of the fourteenth-century diary of Kong Qi 孔齊 (ca. 1310-after 1365). Paul J. Smith, "Fear of Gynarchy in an Age of Chaos: Kong Qi's Reflections on Life in South China Under Mongol Rule," Journal of the Social and Economic History of the Orient 41.1 (1998):1-95.

${ }^{7}$ Pathways to government service available in the late Yuan are discussed in more detail below. For a discussion of the civil service examinations under the Yuan, see Benjamin Elman, A Cultural History of Civil Examinations in Late Imperial China (Berkeley, Los Angeles, London: University of California Press, 2001), especially 29-38. For a discussion of pathways to Ming government, see John Dardess, A Ming Society: T'ai-ho County, Kiangsi, in the Fourteenth to Seventeenth Centuries (Berkeley: University of California Press, 1996), especially 139-69.

${ }^{8}$ The opportunities for forging male bonds during the Song-Yuan-Ming transition—located, for example, in academies and expressed through intellectual lineages — will be discussed in further detail below. Here I only wish to point to the contrast with the late Ming, when socio-economic, intellectual, and cultural changes created far more opportunities for male bonding than were available in the fourteenth century. ${ }^{9}$ McDermott's study engages mostly with the last century of the Ming, for which he notes "a heightened interest in the value of friendship." McDermott, "Friendship and its Friends," 68.

${ }^{10}$ For a biography of Dai Liang in English, see the biography by John D. Langlois, Jr. in Luther Carrington Goodrich and Chaoying Fang, eds., Dictionary of Ming Biography, 1368-1644 (New York: Columbia University Press, 1976) [hereafter $D M B], 1234-37$. The biographical information provided here is largely based on this account, supplemented by the details in the nianpu included in his literary collection. See Dai Liang, Jiuling shanfang ji九靈山房集 (Wenyuange Siku quanshu ed.; Taibei: Shangwu, 1983-86), vol.

1219, nianpu: 1a-11b. On the significance of thinkers like Liu Guan, Huang Jin, and Wu Lai, see John D. Langlois, "Political Thought in Chin-hua under Mongol Rule" in John Langlois, ed., China under Mongol Rule (Princeton: Princeton University Press, 1981), 137-85.

${ }^{11}$ Langlois, "Political Thought in Chin-hua," 159-64. Loyalist poetry gatherings in Pujiang are also discussed in Sun Keguan孫克寬, Yuandai Jinhua xueshu元代金華學術 (Taichung: Donghai daxue, 1975). 
For Yoshikawa Kōjirō, a collection entitled 'Moon Springs Poetry Society' (Yuequan yinshe 月泉吟社) edited in Pujiang county, forms the main example of Southern Song loyalist poetry. See Yoshikawa Kōjirō, Five Hundred Years of Chinese Poetry, 1150-1650 (Princeton: Princeton University Press, 1989), 67-9. See also Fang Yong方勇, Nan Song yimin shiren qunti yanjiu 南宋遺民詩人群體研究 (Beijing: Renmin, 2000), 79-80.

${ }^{12}$ Langlois, "Political Thought in Chin-hua," 163.

${ }^{13}$ Langlois, "Political Thought in Chin-hua," 185.

${ }^{14}$ On the role of Jinhua thinkers in the founding of Zhu Yuanzhang's Ming regime, see Langlois, "Political Thought in Chin-hua" and John Dardess, Confucianism and Autocracy: Professional Elites in the Founding of the Ming Dynasty (Berkeley: University of California Press, 1983).

${ }^{15}$ For the precise details, see Yan Xuanjun 晏选军, “Dai Liang nianpu” 戴良年谱, Hunan renwen keji xuewen xuebao湖南人文科技学院学报 89 (2006):83-88.

${ }^{16}$ For a detailed study of the connection between the Jinhua scholars and Zhu Yuanzhang, see Xu Yongming徐永明, “Wuzhou wenren yu Zhu Yuanzhang” 娿州文人与朱元章, Zhongguo dianji yu wenhua 中国典籍与文化 3 (2002):10-20; and Xu Yongmin, Yuandai zhi Mingchu Wuzhou zuojia qun yanjiu元代

至明初敭州作家群研究 (Beijing: Zhongguo shehui kexue, 2005). See also Langlois, “Political Thought in Chin-hua;" and Dardess, Confucianism and Autocracy, 131-289.

${ }^{17}$ The creation of a local, intellectual tradition specific to Wuzhou丞州 (Jinhua) prefecture during the Yuan dynasty, and Dai Liang's contributions to the creation of that tradition, are discussed by Chen Wenyi 陳雯 怡in her paper "The Rise of Localism? - The Construction of a 'Wu Tradition' in the Yuan Dynasty," Paper Presented at the Annual Meeting of the Association for Asian Studies, Chicago, 2005.

${ }^{18}$ Dai Liang, Jiuling shanfang ji, уиаnхu: 1a-4b. Texts by Jinhua men like Song Lian, Su Boheng蘇伯衡 (1329-ca.1392), Hu Han胡翰 (1307-81), and Wu Chen吳沉 (fl. early Ming ), written after his death and 
included in the final juan of Dai's literary collection, also testify to these ongoing contacts. Dai Liang, Jiuling shanfang ji, 30 .

${ }^{19}$ On Kökö Temür, see for example, Edward L. Dreyer, Early Ming China: A Political History 1355-1435 (Stanford: Stanford University Press, 1982), 53-62.

${ }^{20}$ According to Langlois, there is some doubt as to whether Dai Liang committed suicide. No contemporary account mentions suicide, although Qian Qianyi錢謙益(1582-1664), perhaps shaped by the context of the Ming-Qing transition, suggests that he "most likely took his own life." See $D M B, 1236$. Yuan loyalism was, perhaps as one might expect, much less common than Song loyalism had been. Frederick W. Mote, "Confucian Eremitism in the Yüan Period," in Arthur F. Wright, ed., The Confucian Persuasion (Stanford: Stanford University Press, 1960), 202-40. According to Mote, Yuan loyalists "attained no prominence either in their own time or later." Mote, "Confucian Eremitism," 239.

${ }^{21}$ This account is largely based on Ding Henian's biography in DMB, 1288-89. A more detailed biography of Ding Henian in English can be found in Chen Yuan, Western and Central Asians in China under the Mongols, translated and annotated by Ch'ien Hsing-hai and L. Carrington Goodrich (Berkeley: University of California Press, 1966), 98-110. There is a certain amount of unresolved confusion over the many editions of Ding Henian's writings. His poems appear in no less than eighteen different editions, some claimed to date from the Yuan, others from the Ming and Qing dynasties. On the controversies, see Chen, Western and Central Asians, 155-62. See also Dao Fu导夫, “Ding Henian shiji zhuyao banben xulu” 丁鹤 年诗集主要版本叙录, Ningxia daxue xuebao宁夏大学学报 24 (2003):58-63. I have used the Siku quanshu edition of his works, entitled Henian shij鶴年詩集 (Wenyuange Siku quanshu ed.; Taiwan: Shangwu, 1983-6), vol. 1217.

${ }^{22}$ DMB, 1314-18. In 1372, Zhu Yuanzhang sent Zushan as an envoy to Japan, where he was received favorably by the authorities in Kyoto. Despite their success, relations with Japan broke off between 1383 and 1387. See Dreyer, Early Ming China, 119-20.

${ }^{23}$ Wu Sidao's writings have been preserved; they are entitled Chuncaozhai ji春草齋集, and have been included in the Siku quanshu (Wenyuange Siku quanshu ed.; Taibei: Shangwu, 1983-86), vol. 1232. Wu 
Sidao's 'poetry talks' (shihua 詩話) have been included in Wu Wenzhi吳文治, ed., Ming shihua quanbian

明詩話全編 (Nanjing: Jiangsu guji chubanshe), 188-191.

${ }^{24} \mathrm{DMB}, 1236$ and 1289.

${ }^{25}$ See the article by Joseph Lam in this issue.

${ }^{26}$ For this analysis, I have relied on the editions of their writings that were included in the Siku quanshu. Of course these are by no means unproblematic editions, but since the aim of this paper is neither an exhaustive analysis of these men's works nor a comprehensive biographical study of these individuals, I have chosen the most readily available editions.

${ }^{27} \mathrm{DMB}, 1288$. The daruhachi, a post held by Mongols or semu, served as co-incumbent with a Chinese official at various levels throughout the bureaucracy.

${ }^{28}$ Chen, Western and Central Asians, 101. The evidence Chen draws on includes the observation that Ding Henian was a Muslim by the Hangzhou poet Qu You 盟佑 (1341-1427), who knew Ding in Hangzhou; the use of the surname Ding, which contemporaries at the time noted was a surname often used by Muslims, who had the element 'ding' in their transcribed names, such as his grandfather 'Sams-'d-Din (transcribed as shan-si-ding苫思丁) and his father Jamal al-Din (transcribed as zhi-ma-lu-ding 職馬祿丁); and his mother's burial without a coffin in accordance with Islamic practice, which will be discussed below. Chen, Western and Central Asians, 101-104.

29 "Gaoshi zhuan" is included in Dai Liang, Jiuling shanfang ji, juan 19. Ding Xiaozi zhuan is included in Ding Henian, Ding Henian ji 丁鶴年集 (Changsha: Shangwu, 1941), 1-2; and in Wu Sidao’s collected writings, Chuncaozhai ji, juan 2.

${ }^{30}$ The term semuren literally means 'people of varied categories.' See, for example, Elizabeth EndicottWest, Mongolian Rule in China (Cambridge, MA: Harvard University Council on East Asian Studies, 1989).

${ }^{31}$ Dai Liang, “Gaoshi zhuan,” Jiuling shanfang ji, 19:1a. 
${ }^{32}$ Mo Zi (fl. 49-438 BCE), Mozi墨子, “Jian’ai xia” 兼爱下. The full quote reads: Wu wen wei gaoshi yu tianxia zhe, bi wei qi you zhi shen, ruo wei qi shen, wei qi you zhi qin, ruo wei qi qin, ranhou keyi wei gaoshi yu tianxia 吾聞為高士於天下者，必為其友之身，若為其身，為其友之親，若為其親，然後可 以為高士於天下。

${ }^{33}$ Dai Liang, “Gaoshi zhuan,” Jiuling shanfang ji, 19:5b.

${ }^{34}$ The phrases occur in a poem entitled “For Henian.” Dai Liang, “Ji Henian” 寄鶴年, Jiuling shanfang ji, 25:2a.

${ }^{35}$ The quote from the Book of Changes comes from the Xici shang zhuan 繫辭 (Appended Statements, first commentary), section 9. The Lunyu quote is from chapter 13, Zilu子路, section 21.

${ }^{36}$ Dai Liang, “Gaoshi zhuan,” Jiuling shanfang ji, 19:1b.

${ }^{37}$ Dai Liang, “Gaoshi zhuan,” Jiuling shanfang ji, 19:2a.

${ }^{38}$ Chen, Western and Central Asians, 99, footnote 110.

${ }^{39}$ Dai Liang, "Gaoshi zhuan,” Jiuling shanfang ji, 19:2b. I have followed and slightly amended the translation by Chen Yuan. See Chen, Western and Central Asians, 99.

${ }^{40}$ Dai Liang, “Gaoshi zhuan,” Jiuling shanfang ji, 19:3a.

${ }^{41}$ Ding Henian, Henian shiji, 2:14b.

${ }^{42}$ In Dai's works, see for example the end of the preface for Ding's poetry, where he writes “Ding Henian's high integrity (qingjie清節) and his admirable behaviour (junxing峻行) I have already fully discussed in Gaoshizhuan, so I do not need to discuss them again here.” Dai Liang, “Henian yin gao xu”鶴年吟稿序, Jiuling shanfang ji, 21:3a. In a postface written by Dai Liang for the poems of Ding Henian's older cousin Ma Yuande 馬元德 (jinshi, 1364), Dai writes of Ding's “lofty standards” (gaofeng高風). Dai Liang, “Ti Ma Yuande bozhong shi hou” 題馬元德伯仲詩後, Jiuling shanfang ji, 22:9b. In Ding Henian's works, see for example the phrase "Alone, I retreat from the southern suburbs and become a loftly gentleman/Together we appreciate that in the Eastern Hills are men of true nobility" (du tui nan guo wei gaoshi, gong zhi dong 
ling shi gu hou 獨推南郭為高士, 共識東陵是故侯), a stanza in a poem Ding sent to Dai Liang. Ding

Henian, “Fengji Wang Xuanwei jian cheng Jiuling xiansheng” 奉寄王宣慰兼呈九靈先生, Henian shiji, $2: 14 \mathrm{~b}$.

${ }^{43}$ Wu Sidao's text is included in Ding Henian, Ding Henian ji 丁鶴年集 (Changsha: Shangwu, 1941), 1-2. Part of a different edition of the same text is included in translation in Chen, Western and Central Asians, 244-5.

${ }^{44}$ Wu Sidao, "Ding Xiaozi zhuan” in Ding Henian, Ding Henianji, 1.

${ }^{45}$ Wu Sidao, "Ding Xiaozi zhuan” in Ding Henian, Ding Henianji, 1.

${ }^{46}$ Dai Liang wrote: "The achievements of the three gentlemen in their time were great. The scholars of the realm all appreciate their words.” See Dai Liang, “Henian yin'gao xu” 鶴年吟稿序, Jiuling shanfang ji,

21.2b. Yu Que, jinshi of 1333, was not only a famous poet, but also an active reformer of local policy, notably in Jinhua where he encountered Dai Liang. On Yu Que's reforms in Jinhua, see John Dardess, "Confucianism, Local Reform, and Centralization in Late Yüan Chekiang, 1342-1359," in Hok-lam Chan and Wm. Theodore de Bary, eds., Yüan Thought: Chinese Thought and Religion under the Mongols (New York: Columbia University Press, 1982), 327-374, especially 333-34. Yue Que’s works, entitled Qingyang xiansheng wenji青陽先生文集, are extant. Sa-du-la had other Han-Chinese friends, such as the musician and Daoist painter Leng Qian冷謙 (1310-1371). DMB, 802-3.

${ }^{47}$ Dai Liang, Jiuling shanfang ji, 21.2a.

${ }^{48} \mathrm{DMB}, 1234-5$.

${ }^{49}$ After the Jurchen captured the Song capital in 1127, fighting continued between Jurchen and Song forces until 1142. Hoyt Cleveland Tillman and Stephen H. West, "Introduction" in Hoyt Cleveland Tillman and Stephen H. West, eds., China under Jurchen Rule: Essays on Chin Intellectual and Cultural History (Albany: State University of New York Press, 1995), 3.

${ }^{50}$ Tillman and West, "Introduction," 3. 
${ }^{51}$ See Peter K. Bol, "Seeking Common Ground: Han Literati under Jurchen Rule," Harvard Journal of Asiatic Studies 47.2 (1987): 461-538. See also the studies in Tillman and West, eds., China under Jurchen Rule.

${ }^{52}$ Herbert Franke, “The Chin Dynasty," in Herbert Franke and Denis Twitchett, eds., The Cambridge History of China, vol. 6: Alien Regimes and Border States, 907-1368 (Cambridge: Cambridge University Press, 1994), 215-320 (see page 265).

${ }^{53}$ Richard L. Davis, Wind Against the Mountain: The Crisis of Politics and Culture in Thirteenth-Century China (Cambridge, MA: Harvard University Council on East Asian Studies, 1996). For a review of Davis' work, see Paul J. Smith, "Review of Wind Against the Mountain: The Crisis of Politics and Culture in Thirteenth-Century China," Harvard Journal of Asiatic Studies 58.2 (1998): 603-14. Davis' study suggests that heroic displays of martyrdom were widespread, and that "incalculable numbers of southern men and women willfully laid down their lives." Davis, Wind Against the Mountain, 24-5. Smith finds these numbers inflated, and suggests instead that "most Song generals, local elites, officials, students, and commoners submitted to the Mongols to save their families and their communities, more often than not taking office under the Yuan when the chance was offered." Smith, "Review," 611-12.

${ }^{54}$ Smith, "Review," 604. See also Jennifer W. Jay, A Change in Dynasties: Loyalism in Thirteenth-Century China (Bellingham, WA: Center for East Asian Studies, 1991), and Jennifer W. Jay, "Memoirs and Official Accounts: The Historiography of the Song Loyalists," Harvard Journal of Asiatic Studies 50.2 (1990):589612.

${ }^{55}$ The term "transition" is used, for example, in Paul Jakov Smith and Richard von Glahn, eds., The SongYuan-Ming Transition in Chinese History (Cambridge, MA: Harvard University Asia Center, 2003). For a discussion of the cyclical pattern of periods of centralist activism followed by a turn towards localism, see Peter K. Bol, “The 'Localist Turn' and 'Local Identity' in Later Imperial China,” Late Imperial China 24.2 (2003):1-50. The work by Robert P. Hymes has also chronicled the transition of centralist concerns to a localist outlook, first in social and marital strategies in Statesmen and Gentlemen: The Elite of Fu-Chou, Chiang-Hsi, in Northern and Southern Sung (Cambridge: Cambridge University Press, 1986), and then in religious practices in Way and Byway: Taoism, Local Religion, and Models of Divinity in Sung and Modern China (Berkeley: University of California Press, 2002). My own work on temples and locality in Jiangxi 
province also chronicles continuities rather than disruptions during the transition from Song to Yuan rule. See Anne Gerritsen, Ji'an Literati and the Local in Song-Yuan-Ming China (forthcoming). ${ }^{56}$ See also the introduction to this issue by Martin Huang on the differences between Song, Yuan and Ming loyalism. On the links between Song and Ming loyalism, see Zhao Yuan 趙園, Ming Qing zhiji shidafu yanjiu 明清之際士大夫研究 (Beijing: Beijing daxue, 1999), especially 269-88.

${ }^{57}$ Take the Song scholar Liu Chenweng劉辰翁(1232-1297), for example. Liu was a protégé of Jiang Wanli 江萬里 (1198-1275), and Liu was deeply moved when Jiang drowned himself. Liu Chenweng never served again, and spent over twenty years at home in Luling盧陵, Jiangxi. That loyalist sentiment, however, did not prevent him from encouraging his son, Liu Jiangsun 劉將孫 (b.1257), to seek office under the Yuan, and from maintaining personal connections with Yuan officials, as his collected works testify. Xuxi ji 須溪集 (Wenyuange Siku quanshu edition, Taibei: Shangwu, 1983-86). See also Jay, A Change in Dynasties, 167-173, and Fang Yong, Nan Song yimin shiren, 92.

${ }^{58}$ This was the case, for example, for Dai Liang's teachers Huang Jin and Liu Guan. They themselves had been students of Fang Feng方鳳 (1240-1321), one of the famous Song loyalist poets from Pujiang, and despite their admiration for their teacher, Huang and Liu both served the Yuan. On Fang Feng, see Fang Yong, Nan Song yimin shiren, 78-82.

${ }^{59}$ Jay, A Change in Dynasties, 257-59.

${ }^{60}$ See Yan Xuanjun晏选军, “Dai Liang kao lun” 戴良考论in Zhongguo wenxue yanjiu中国文学研究 73 (2004):49-53 .

${ }^{61}$ Jay, A Change in Dynasties, 259.

${ }^{62}$ Dai Liang expresses his sense of isolation and his lack of deep connections in “Tou zhiji shu,”投知己書， Jiuling shanfang ji, 10.8a-10a. The text discusses Dai's longing for true friends and the frustrations over the difficulties he has experienced in finding true friends.

${ }^{63}$ In Feng Menglong's vernacular story, “The Chicken-and-Millet Dinner for Fan Juqing, Friend in Life and Death," discussed by Kimberly Besio, Feng refers to the flower associated with "the quintessential 
unappreciated scholar Tao Yuanming," the chrysanthemum. See the article by Besio in this issue. For a brief introduction to Tao's life and work, see, for example, Stephen Owen, ed., An Anthology of Chinese Literature: Beginnings to 1911 (New York: W.W. Norton, 1996), especially page 225.

${ }^{64}$ Dai Liang, Jiuling shanfang ji, 24.12b-14a.

65 'Among lakes and rivers' is a quote from Tao Yuanming. It appeared in his poem Yu Yin Jin'an bie 與殷 晉安別 (“Taking leave from Yin Jin'an”). The full line reads: “Those with talents do not become hermits, among the rivers and lakes many live in poverty" (liang cai by yin shi, jiang hu duo jian pin 良才不隱世, 江湖多賤貧.) Over time, the "rivers and lakes" came to refer to the "private domain" that lies "beyond the control of the government." See the brief discussion of this in Huang, Negotiating Masculinities, 104. ${ }^{66}$ Ding Lingwei was said to be a man from Liaodong who lived during the Han dynasty. He studied the Way at Lingxu靈虛 Mountain, and when he had become an immortal, he transformed into a crane. He flew home to Liaodong, one thousand years after he had left and perched on a high column. When a youth attempted to shoot him with his bow and arrow, he flew up and spoke the words: "There is a bird, a bird named Ding Lingwei; having been away from home for a thousand years he only returns now. The city and its outskirts are as before, but the people have all changed. Why not study to be an immortal, as the grave tombs keep piling up?" The tale is attributed to Tao Yuanming.

${ }^{67}$ 'East of the walls' (qiang dong 牆東) is a common expression for the residence of a hermit.

${ }^{68}$ Dai Liang, “Yi Henian you fu” 憶鶴年有賦, Jiuling shanfang ji, 17.6a.

${ }^{69}$ On these issues in Tao Yuanming's life, see Charles Yim-tze Kwong, Tao Qian and the Chinese Poetic Tradition: The Quest for Cultural Identity (Ann Arbor: Center for Chinese Studies, 1994), especially 21-49.

${ }^{70}$ As John Dardess has shown, the "recommendation route into Ming government was an important channel of opportunity for roughly the first century of Ming rule." Dardess, A Ming Society, 142.

${ }^{71}$ For a detailed discussion of the group and its attitudes and proposals, see Dardess, "Confucianism, Local Reform, and Centralization," 342-50.

${ }^{72}$ The exact details of these restless years are readily available in a multitude of English-language materials, including F.W. Mote, “The Rise of the Ming Dynasty, 1330-1367” in F.W. Mote and Denis Twitchett, eds., 
The Cambridge History of China, vol. 7: The Ming Dynasty: 1368-1644 (Cambridge: Cambridge

University Press, 1994), 11-57; Dreyer, Early Ming China; John Dardess, Confucianism and Autocracy:

Professional Elites in the Founding of the Ming Dynasty (Berkeley: University of California Press, 1983).

${ }^{73}$ Wu Sidao, “Jiuling shanfang ji” 九靈山房記, Chuncaozhai ji 1:50b.

${ }^{74}$ John Langlois's biography of Dai Liang in DMB suggests that it was Dai Tang戴堂, the son of Zhejiang

Imperial Commissioner Dai Zhao戴昭 (825-82) who migrated from Chang'an to the foot of Jiuling

Mountain. DMB, 1234. The nianpu for Dai Liang included in the Wenyuange Siku quanshu edition of Jiuling shanfang ji confirms this. Dai Liang, Jiuling shanfang ji, nianpu: 1a.

${ }^{75} \mathrm{Wu}$ Sidao, "Jiuling shanfang ji," Chuncaozhai ji, 1:50b.

${ }^{76} \mathrm{Wu}$ Sidao, “Jiuling shanfang ji,” Chuncaozhai ji, 1:50b.

${ }^{77}$ Much has been written about the political connections between the Jinhua thinkers and Zhu Yuanzhang regime. See, for example, Langlois, "Political Thought in Chin-hua under Mongol Rule," and Dardess, Confucianism and Autocracy, passim.

${ }^{78} \mathrm{Wu}$ Sidao, “Jiuling shanfang ji,” Chuncaozhai ji, 1:51b.

${ }^{79}$ Wu Sidao, “Fu de Wuwang bishu gong Tao Kan dushu tang ershi song Ding Henian gui Wuchang” 賦得 吳王避暑宮陶㑆讀書堂二詩送丁鶴年歸武昌, Chuncaozhai ji, 2:7a-8a. This quote is on $8 \mathrm{a}$.

${ }^{80}$ Wu Sidao, "Fu de Wuwang," Chuncaozhai ji, 2:8a.

${ }^{81}$ Wu Sidao, "Fu de Wuwang," Chuncaozhai ji, 2:7b.

${ }^{82}$ Ding Henian, “Ci Wu Jishan xiansheng jianji xun” 次烏繼善先生見寄韻, Henian shiji, 1:6a-b

${ }^{83}$ Ding Henian, “Ci Wu Jishan,” Henian shiji, 1:6b.

${ }^{84}$ Martin Huang's choice to refer to "masculinities" rather than "masculinity" in Negotiating Masculinities is significant, and I have followed his suggestion that there is no "overarching definition of 'Chinese masculinity’." Huang, Negotiating Masculinities, 9. 
${ }^{85}$ For example, in his study on masculinity, Kam Louie sees participation in the civil service exams as 'a respected part of the masculine image.’ Kam Louie, Theorising Chinese Masculinity, 19.

${ }^{86}$ See also the Introduction to this issue by Martin Huang for a discussion of the significance of the examination system for the creation and development of ongoing male bonds.

${ }^{87}$ By 1333 , for example, only two percent of all officials were jinshi degree holders. John Dardess, "Shunti and the end of Yüan rule," Cambridge History of China, vol. 6, 564.

${ }^{88}$ Hymes, Way and Byway; Bol, "The 'Localist Turn'."

${ }^{89}$ On poetry and membership of poetry circles as significant alternative male occupation during the Yuan dynasty, see Yoshikawa, Five Hundred Years of Chinese Poetry, 1150-1650, especially 66-101. On the medical profession as alternative occupation, see Robert P. Hymes, "Not quite Gentlemen? Doctors in Sung and Yuan," Chinese Science 8 (1987):9-76. Ding Henian earned his living for a time by selling medicine, and Dai Liang was well-known for his medical expertise. On this aspect of Dai Liang's life, see Angela Kiche Leung, "Medical Learning from the Song to the Ming," in Paul Jakov Smith and Richard von Glahn, eds., The Song-Yuan-Ming Transition in Chinese History (Cambridge, MA: Harvard University Asia Center, 2003), 374-98.

${ }^{90}$ Dai Liang, Jiuling shanfang ji, 19:4a.

${ }^{91}$ Dai Liang, Jiuling shanfang ji, 19:5a.

${ }^{92}$ Looking at encounters between male and female is, of course, not the only way to approach masculinity and to understand the construction of gender identities. The recent study by Bettine Birge, for example, suggests our understanding of Yuan dynasty gender identities should take account of patterns of female inheritance. Her important work suggests that the combination of neo-Confucian ideologies and Mongol practices, in particular the levirate, led to the formulation of stricter prohibitions on the remarriage of widows and female ownership of property. In other words, one might say that Birge detects a deterioration in the status of women from the Yuan dynasty onwards. See Bettine Birge, Women, Property, and Confucian Response in Sung and Yüan China (960-1368) (Cambridge: Cambridge University Press, 2002). See also the extended review of her work and the scholarship on the issue by Joseph McDermott, "Women of Property in China, 960-1368: A Survey of the Scholarship," International Journal of Asian Studies 1.2 (2004):201-222. 
${ }^{93}$ Huang, Negotiating Masculinities, especially chapters 2 and 4.

${ }^{94}$ Beverly Bossler, "Gender and Empire: A View from Yuan China," Journal of Medieval and Early Modern Studies 34.1 (2004):197-223.

${ }^{95}$ Bossler, "Gender and Empire," 214.

${ }^{96}$ Bossler, "Gender and Empire," 205-6.

${ }^{97}$ Bossler, "Gender and Empire," 211.

${ }^{98}$ Bossler, "Gender and Empire," 212.

${ }^{99} \mathrm{Wu}$ Sidao, for example, wrote the biography of Loyal Woman Qiu (Wu Sidao, “Qiu jiefu zhuan” 丘節婦

傳, Chuncaozhai ji, 2:17b-19a), the biography of Loyal Woman Zhang (Wu Sidao, “Zhang jiefu zhuan” 張

節婦傳, Chuncaozhai ji, 2:20b-21b), and an inscription for the shrine of Lady Tan, who had been brutally

murdered at the hands of Mongol invaders in Yongxin永新county, Ji’an吉安 prefecture, in Jiangxi province, where Wu served as magistrate (see Wu Sidao, “Tan jiefu citang ji” 譚節婦祠堂記, Chuncaozhai ji, 1:12a-14a). He also wrote a series of poems for Lady Tan and for several other women. See Wu Sidao, “Cai jiefu shi”蔡節婦詩, Chuncaozhai ji (1629; a 1986 microfilm of this text, produced by the National Central Library (Guoli zhongyang tushuguan國立中央圖書館) in Taiwan, is available in the Bodleian Library, Oxford, U.K.), 1:6b. The poem for Lady Tan can be found in Wu Sidao, “Tan jiefu shi” 譚節婦詩, Chuncaozhai ji (1629) 4:11b. On Wu Sidao's interest in Lady Tan, see also my article entitled “The Story of Chaste Lady Tan: The Meaning of 'Local' in Song-Yuan-Ming China” (unpublished manuscript). Ding Henian's works include a poem written for the mother of a friend, and other works dedicated to faithful women. See Ding Henian, “Li luan pian” 離鸞篇, Henian shiji, 2:3a-b; Ding Henian, “Hu jiefu”胡節婦, Henian shiji, 2.3a-b; Ding Henian, “Le jiefu”樂節婦, Henian shiji, 2.3b. Dai Liang was said to be deeply moved by the death of his older sister, who had taught him until he was eight, when she married and moved away, but he stayed close to her until her death. See Dai Liang's nianpu included in Jiuling shanfang ji, nianpu: 1a-b. For Dai Liang's writings about loyal women, see for example, the grave inscription for 
Chaste Lady Wei in Dai Liang, “Wei jiefu” 衛節婦, Jiuling shanfang ji, 14:15b-17a; the biography written for Chaste Lady Wang in Dai Liang, “Wang jiefu zhuan” 汪節婦傳, Jiuling shanfang ji, 27:5a-6a; or the muzhiming written for Chaste Lady Tang in Dai Liang, “Tang jiefu Jiang shi muzhiming” 唐節婦姜氏墓誌 銘, Jiuling shanfang ji, 29:21b-23a.

${ }^{100}$ Ding Yue'e's biography is the first biography in the 'Biographies of famous women' (lienü列女) chapter, juan 301 in the Mingshi明史 (1739, reprint, Beijing: Zhonghua shuju, 1989). Her biography is also included in juan 245 of the Xin Yuanshi (1920, reprint, Beijing: Zhonghua shuji, 1988). For a brief study of Yue’e, see Ding Hong丁宏, “Huizu funü renwu zhuanlüe” 回族妇女人物传略Heilongjiang minzu congkan黑龙江民族丛刊 (1994):62-5.

${ }^{101}$ Wuhu county is located on the Yangzi river, roughly $90 \mathrm{~km}$ upriver (i.e. south) from Nanjing in Taiping prefecture. It would have been relatively straightforward to travel downriver along the Yangzi from Wuchang where Yue'e was born, to Wuhu county.

${ }^{102} \mathrm{Wu}$ Sidao, Chuncaozhai ji, 2:16a.

${ }^{103} \mathrm{Wu}$ Sidao, Chuncaozhai ji, 2:16b.

${ }^{104}$ Wu Sidao, “Tan jiefu citang ji” 譚節婦祠堂記, in Chong Tianzi蟲天子, ed., Xiangyan congshu香艷叢 書 (reprint; Beijing: Renmin wenxue chubanshe, 1994), 1657-1658.

${ }^{105} \mathrm{Wu}$ Sidao, Dai Liang and Ding Henian all had reputations based on their literary writings. On Dai Liang as a literary figure, see, for example, Yan Xuanjun, "Dai Liang kao lun."

${ }^{106}$ Bossler, “Gender and Empire,” 212.

${ }^{107}$ Bossler, "Gender and Empire,” 215.

${ }^{108}$ Some interesting work has been done on gender and ethnicity in the Qing context. Angela Zito's book, Of Body and Brush, for example, discusses the masculinity of the Manchu ruling minority in contrast to Han ideals of filiality and literacy. Angela Zito, Of Body and Brush: Grand Sacrifice as Text/Performance in Eighteenth-Century China (Chicago: University of Chicago Press, 1997), especially 13-64. Earlier, Robert van Gulik had already pointed to the contrast between the martial masculinity of the Manchu's and 
the Han scholarly ideal. Robert van Gulik, Sexual Life in Ancient China: A Preliminary Survey of Chinese Sex and Society from ca. 1500 B.C. till 1644 A.D. (Leiden: E.J.Brill, 1974), 245-62. See also Brownell and Wasserstrom, "Introduction: Theorizing Femininities and Masculinities" in Brownell and Wasserstrom, eds., Chinese Femininities/Chinese Masculinities, 19. Much less has been done on gender and ethnicity in the earlier, Mongol-Han encounter of the Song-Yuan transition. An exception is Song Geng, "Wax Spearhead: The Construction of Masculinity in Yuan Drama” Tamkang Review 30.1 (1999):209-54.

${ }^{109}$ Davis, Wind Against the Mountain, 21.

${ }^{110}$ Smith, "Gynarchy in an Age of Chaos," 83.

${ }^{111}$ Dai Liang, “Tang jiefu Jiang shi muzhiming,” Jiuling shanfang ji, 29.23a.

${ }^{112}$ Bossler, "Gender and Empire," 211-215.

${ }^{113}$ The reference is to Han Wudi, who asked "Is it real or is it not?" when he saw the likeness of his deceased Lady Li李夫人.

${ }^{114}$ Ding Henian, Henian shiji, 3:5b-6a.

${ }^{115}$ Zhang Han, a general of the state of Wu during the Western Jin (265-316), was once reminded of his home and its edible delicacies while he was on campaign, and decided on the spot to leave the quest for fame and high honors behind and return home. Guan Ning (158-241) lived in Wei when the Han dynasty fell, and retreated to the mountains for more than 30 years.

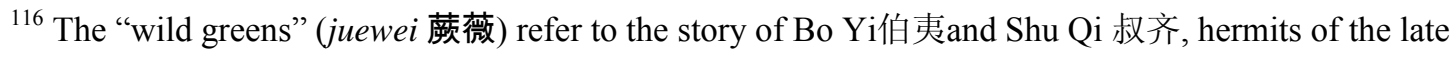
Shang, who chose to eat wild greens rather than the grains of the Zhou dynasty, and starved to death.

${ }^{117}$ Wu Sidao, “Jiuling shanfang ji,” Chuncaozhai ji, $1.51 b$.

${ }^{118}$ Norman Kutcher, “The Fifth Relationship,” 1615-29.

${ }^{119}$ Dai Liang, Jiuling shanfang ji, 19:5b.

${ }^{120}$ Dai Liang, “Henian yin gao xu” 鶴年吟稿序, Jiuling shanfang ji, 21.2a-b. According to Chen Yuan, Dai Liang wrote this preface for Ding Henian's poems in 1366. Chen Yuan, Western and Central Asians, 293.

${ }^{121}$ Dai Liang, "Henian yin gao xu," Jiuling shanfang ji, 21:1b. 